\title{
“A MIRROR IN WHICH EVERYONE DISPLAYS THEIR IMAGE”: IDENTITY CONSTRUCTION IN DISCOURSE
}

\author{
Olga A. Leontovich \\ Volgograd State Socio-Pedagogical University \\ 27 Lenina prosp., 400066, Volgograd, Russia

\section{«ЗЕРКАЛО, В КОТОРОМ КАЖДЫЙ ПОКАЗЫВАЕТ СВОЙ ЛИК»: ДИСКУРСИВНОЕ КОНСТРУИРОВАНИЕ ИДЕНТИЧНОСТЕЙ}

\author{
О.А. Леонтович \\ Волгоградский государственный социально-педагогический университет \\ 400066, Волгоград, Россия, пр. им. В.И. Ленина, д. 27
}

If this issue of the journal were to be orchestrated, it would have two leading motives: identity and discourse. Identity grows out of communication and becomes a complex interplay of collective and individual personality features. Scholars emphasise the dialogical character of identity construction and view it as a result of negotiation and renegotiation in a social setting. The discursive construction of identity by means of language and other modes of interaction has to a certain extent been implemented in the Russian research paradigm through the notion of "linguistic personality".

Due to the interest for interconnection and mutual influence of social practices and discourse, a number of papers in this issue produced by scholars from different countries and educational institutions draw upon Critical Discourse Analysis as a theoretical framework. CDA, which is rather a perspective than a coherent theory, goes back to the ideas of M. Foucault (Foucault 1977) who researched representational features of discourse as an instrument of power. The basic principles of CDA are formulated in the seminal book "Language and Control" (Fowler et al. 1979). The founders of CDA are a "quartet" of scholars who do not form one research school but each have their individual history: N. Fairclough (textually oriented discourse analysis), R. Wodak (discourse historical approach), T.A. van Dijk (text linguistics and cognitive linguistics) and P. Chilton (linguistics, semiotics and communication studies) (Blommaert 2005: 21).

The view of language as a social practice implies that discursive events and situations are dialectically linked to institutions and social structures which frame them (Fairclough, Wodak 1997). CDA scholars believe that it is not enough to reveal the social dimensions of language use - it is necessary to critically analyse social wrongs such as prejudice, unequal access to power, privileges, material and symbolic resources (Fairclough 2009), expose those who are responsible for the inequality (van Dijk 1986), 
resist and counteract "enactments of power abuse as transmitted in private and public discourses" (Tenorio) and participate in forming and transforming different social structures (Fairclough, Wodak 1997).

Though the themes of identity and discourse are intertwined in the publications included in this issue, it is tentatively divided into two parts: "Identity in Communication" and "Text and Discourse".

\section{IDENTITY IN COMMUNICATION}

Individuals possess features of big and small groups they are part of. They primarily belong to humanity capable of, according to G.I. Bogin's expression, “appropriating language" (Bogin 1980: 3). Universal traits inherent in any person using language as a form of communication account for the unity of humankind. A. Wierzbicka indicates that if there were no common base uniting different cultures and societies, the conceptual worlds connected with different languages would be mutually impenetrable (Wierzbicka 1996: 320).

The optimal correlation between personal traits and those acquired as a requirement of a group, organisation, nation, etc. gives an individual the sense of identity which, on the one hand, does not stem from blind conformism and, on the other, creates the awareness of "self" existing in harmony with society. The multi-layered identity based on a combination of psychophysiological, social, ethnic, cultural and linguistic differences, becomes more complex as a person is included in bigger social units. Scholars compare modern personality conceptualization to a 'Russian Doll' where different identities are hierarchically stacked (Herrmann et al. 2004).

The modern world brings forth new identity forms and implementations. Geographic mobility, globalization, ethnic and cultural polyphony create multiple identities. V.S. Kurske defines them as "self-identification with $<\ldots>$ two or more ethnic cultures": "alongside with traditional diasporas, such as Jews, Armenians, Greeks, Germans, etc., there emerge new ethnic groups with multilevel awareness, which integrates different elements of civilian, regional, confessional and ethnic identities" (Kurske 2011). Former demarcation of territories between different ethnic groups is substituted by the "de-territorialisation of communities" (Leung et al. 2009). In the context of contemporary cultural pluralism (multiculturalism, transnationalism) the best term to characterize the dynamics of personal and collective identity is "transformation".

The paper by Franco Zappettini "Transnationalism as an Index to Construct European Identities: An Analysis of 'Transeuropean' Discourses" treats identities as "dynamic, multiple and fluid constructs". The nature of transnationalism is elucidated through the research of the European Union and the complicated processes of "transformations of Europe(anness)". The paper seeks to examine the new post-national identities and forms of belonging, which are of special interest for researchers because, according to the author, they emerge from discursive negotiation rather than exist in reified forms. Transnational discourses constructed on the levels of interpersonal, public and mass communication are investigated "from a bottom-up/grassroots perspective".

The study explores the dialogical nature of this process and the role of linguistic devices and discursive strategies in the formation of new identities. The paper has an 
overall focus on indexicality in the broad sense (e. g. regional accents, ideological and social connotations, different kinds of implicatures, temporal, spatial, personal and ideological positioning, etc.) and deixis in a narrower sense (pronouns, adverbs, labels, etc. that "signal (dis)alignment with one particular group identity"). The author discusses the 'de-territorialisation' of English as a tool used for intercultural communication and the evolution of its cultural and cognitive connotations, as well as the change of European identity under the influence of bilingualism. The world sees the emergence of 'in-between' identities of people who do not feel completely assimilated Europeans because of insufficient linguistic competency, differences in public and family discourses, struggle between the moral obligation to society and the affective dimension of groupness, etc. According to Zappettini, "nationhood becomes increasingly volatile" giving way to Europeanness as a form of transnationalism.

Zappettini's ideas are in line with the work by Jean-Marc Dewaele and Laura Hryniewicz devoted to the intercultural identity of Slovak-Roma schoolchildren in the UK. The authors believe that in today's globalised world the significance of "where you are 'originally from' $<\ldots>$ is becoming less and less straightforward". Dewaele and Hryniewicz examine the impact of mobility, transnational migration and cultural pluralism on Slovak-Roma schoolchildren living in the UK. The readers of the journal will certainly appreciate the discussion of the ways in which identity is constructed in a multilingual society where the prestige and value of different languages, as well as their association with power, status and social roles, are believed to be unequal. There is voluminous linguistic literature devoted to the problems of cultural imperialism, language as a tool of domination and stereotyping, an object of discrimination, perception of individuals on the basis of their linguistic competency, absorption of minority languages by bigger ones and, as a consequence, death of languages. The loss of a language is closely associated with the loss of cultural identity, whereas bilingualism or polylingualism can perform different functions and highlight different aspects of personal and group identity.

In addition to ethnicity, Dewaele and Hryniewicz take into account such aspects of the Slovak-Roma identity as nationality, age and language practices. The term "Roma" (or Romani people) itself creates certain difficulties of interpretation as it does not include a homogeneous group of people but is an umbrella term for different subgroups. The life of the Slovak-Roma schoolchildren in the UK presupposes the use of English as the main language. The authors point out that the children "must negotiate between criticism from the dominant culture for not speaking English but perhaps even stronger criticism from their own ethnic in-group for speaking it". By giving 'voice' to SlovakRoma schoolchildren during interviews, Dewaele and Hryniewicz show that codeswitching (in this case — switching of languages) can be done for the following reasons: 1) achievement of understanding with the interlocutor(s);2) realisation of ingroupoutgroup dichotomy; 3) ability to live in the new communication environment.

The problem of deixis as an index of personal identity in the Japanese language is discussed in Etsuko Oishi's article "Discursive Functions of Japanese Personal Pronouns". The author grants that through identifying the functions of first- and secondperson pronouns in an illocutionary act it is possible to consistently characterise com- 
municators from the point of view of their gender, social standing and the formality level of discourse. The Russian readers will be interested in the differentiation of the first-person male (watakushi, watashi, boku и ore) and female (watakushi, watashi и $a t a s h i$ ) pronouns, which indicate how the speakers position themselves depending on the character of the discourse and social context. The second-person pronouns also indicate gender (male anata, kimi, anta and omae; femle anata and anta), the positioning of communicators in time and space, as well as the degree of equality, status and power distance between them.

The paper "Narratives about Displacement and Stigmatization of Identities" by Maria do Carmo Oliveira and Carla Mirelle Lisboa examines the problem of individuals' self-perception and their perception by others through their narratives, which results in alternative identities. It is well known that narrators possess great power - the ability to decide what to say and which information to withhold, in which order to present the events and how to explain the motives of their actions. The authors research the mechanism of constructing the narrator's discursive identity through the narrative of a woman from the state of Rio de Janeiro who lost her house to heavy rainstorms and became homeless with her seven young children. The dominant themes of her discourse are motherhood and female fulfilment. At the same time she uses double standards evaluating her own and others' life situations, "distances herself from the homeless category" and is critical of the deviant behaviour of people categorized as 'homeless'.

Barbara Loester's article "'A significant part of an insignificant identity': tradition, globalisation and the re-articulation of North-East Scots" addresses a topic which was not thoroughly researched before but can shed light on the shaping of identity of minority language users - the status of Scots (a language, a dialect or a non-standard variety?). The main focus is on North-East Scots as "an important identity marker for its speakers", especially in small towns and rural areas, where it is held in high esteem due to the belief that the varieties spoken there are "the most "uncorrupted' and 'pure"". In the interviews carried out by the author the respondents argue that the status of the language and their identity can be preserved through the use of North-East Scots rather than English, the existence of printed materials and the study of literature in their native language.

\section{TEXT AND DISCOURSE}

The second part of the journal continues the discussion of discourse from the previous issues. In the context of the present publication discourse becomes an integrative factor which unites different researches and topics.

Georgii G. Khazagerov's paper "Cultivation of Communicative Space: Polemical Eloquence vs. Epideictic Eloquence" differentiates the influence of polemic and epideictic genres on horizontal and vertical communication flows, as well as their contribution to culture. Epideictic discourses find new modes of realisation in propaganda, advertisement, didactics, etc.; polemic discourses, in their own turn, are investigated on the material of both dialogical and monological texts. The author reflects on the complexity of contemporary communicative space and the possibility of harmonious combination of polemic and non-polemic genres in modern society. 
The paper by Irina A. Schirova "Text as an Element of Integrative Scientific Space" is devoted to the correlation of dichotomies science and arts, scientific truth and artistic truth, scientific worldview and artistic worldview, scientific cognition and perceptual cognition, scientific information and aesthetic information and their role in text production. The genre of essay, which, according to the author, is both a piece of art and science, is regarded as a combination of those oppositional characteristics, the borders between which are flexible and conceptually interconnected. The paper postulates a holistic approach towards texts, existing and functioning on the intersection of emotio and ratio.

Marklen E. Konurbaev's work "Redefining Neutrality in Language and Discourse" deals with the communicative value of linguistic units against the background of contextual neutrality, which intensifies the aesthetic perception of stylistically marked elements and is viewed as the basis of stylistic variability. The author believes that different contexts influence the degree to which the semantic potential of linguistic units is realised. By using examples from texts belonging to different functional styles, Konurbaev shows how the zones of stylistic impact are created "molding the organic auditory and visual whole in a text".

The article "A Discourse-Based View in Interdisciplinary Approaches to Fictional Text Analysis" by Alcina Sousa is devoted to pedagogical stylistics. The author uses CDA to show the potential impact of literary works in discursive and social contexts. She regards reading not as a mechanical exercise aimed at comprehension but as an integrative skill and a meaningful kind of dialogical activity in the teaching process. Due to this approach, discourse analysis can become a key to the creative perception of fictional text and an interactive process of meaning generation by writers and their reading audience.

Elizaveta G. Kotorova's paper proposes an innovative approach to the comparative analysis of basic units of intra- and intercultural communication. She suggests employing speech behaviour pattern as the basic unit of communication and believes that its illocutionary content and general organization are universal, whereas its linguistic realization relies on a particular culture and may have significant variations from one language to another. The paper contains a detailed description of the pattern structure and illustrates the possibilities of its application on the example of the speech act "promise" in the Russian and German languages.

The issue is concluded by Natalia V. Gladkaya's article "Logoepistems in Creolised Texts of Internet Discourse" based on the material of memes, demotivators, Internet comics and other specific Internet genres. Logoepistems are described as transformed precedent statements in Internet texts with an interplay of their verbal and visual components based on different meanings of one and the same lexeme. The author suggests a classification of logoepistemic units taking into account their culturally specific features and the audience's background knowledge.

The discussion of sociolinguistic problems will be continued in the next issue of the journal devoted to the commodification of the Russian language, with the participation of Aneta Pavlenko (Oslo University) and Sebastian Muth (University of Fribourg, Switzerland). 


\section{RU}

Лейтмотивом предлагаемого читателю нового выпуска журнала стала тема идентичности, теснейшим образом связанная с проблемами дискурса. Идентичность вырастает из коммуникации и выступает как сложное переплетение коллективного, преломляемого через призму индивидуальности, и индивидуального, вкрапленного в коллективное. Наибольший интерес для лингвистов представляет дискурсивное конструирование идентичности средствами языка и иных коммуникативных форм, в известной степени воплотившееся в российской научной парадигме посредством понятия языковой личности. Западные исследователи преимущественно пишут о формировании идентичности как результате переговорного процесса (negotiation and renegotiation of identities).

Личностная идентичность не может сложиться вне человеческого сообщества, ибо она предполагает отождествление себя с другими и анализ себя на фоне других. Именно вниманием к социальным процессам можно объяснить особый интерес исследователей, представляющих в настоящем выпуске журнала разные страны, научные школы и учебные заведения, к критическому дискурс-анализу (КДА). Эта научная парадигма и выросший из нее исследовательский метод восходят к идеям М. Фуко (Foucault 1977), который изучал репрезентационные свойства дискурса как инструмента власти. Основы КДА заложены в книге "Language and Control" (Fowler et al. 1979). Основные представители КДА - «квартет» ученых, которые не составляют единую исследовательскую группу, а каждый имеет свою индивидуальную историю: Н. Фэрклаф (системно-функциональная лингвистика), Р. Водак (интеракциональные исследования), Т.А. Ван Дейк (лингвистика текста и когнитивная лингвистика), П. Чилтон (лингвистика, семиотика, коммуникативистика) (Blommaert 2005: 21).

Внимание сторонников КДА сосредоточено на пересечении языка / дискурса / речи / социальной структуры. Н. Фэрклаф трактует дискурс как промежуточный уровень между текстом как таковым и социальным контекстом, осуществляющим связь между внутренними отношениями в тексте и его внешними отношениями (Fairclough 2003: 37). Дискурсы не только представляют мир в том виде, в котором он существует или видится нам, - они также проективны и изображают возможные миры, отличные от реального - такие, которые говорящие хотели бы создать (Там же: 124). Таким образом, к обозначенным выше признакам дискурса добавляется его способность конструировать социальный мир коммуникантов.

С точки зрения приверженцев КДА, недостаточно выявить социальные измерения использования языка - необходимо сделать их объектом моральной и политической оценки; их изучение должно влиять на общественные процессы: наделять властью тех, кто ею не обладает, давать право голоса тем, кто его лишен, вскрывать злоупотребления властью, поднимать людей на борьбу с социальной несправедливостью. Таким образом, критический дискурс-анализ должен способствовать активному вмешательству в социальные практики и давать рекомендации в отношении того, как это следует делать (Blommaert 2005: 25), играть роль в конструировании социальных структур и их трансформациях (Fairclough, Wodak 1997). 
Хотя темы идентичности и дискурса органично переплетаются в представленных публикациях, выпуск журнала с достаточной степенью условности поделен на два раздела: «Идентичность в коммуникации» и «Текст и дискурс».

\section{ИДЕНТИЧНОСТЬ В КОММУНИКАЦИИ}

Личность заключает в себе признаки больших и малых групп, в состав которых она входит. В первую очередь, это принадлежность к человечеству как единому целому, способному, по выражению Г. И. Богина, «присваивать язык» (Богин 1980: 3). Универсальные черты, присущие любому человеку, который владеет языком как средством коммуникации, обусловливают единство человечества на основе этого признака. А. Вежбицкая пишет о том, что если бы не существовало общей базы, объединяющей различные культуры и социумы, «различные понятийные миры, связанные с различными языками, были бы взаимонепроницаемы» (Вежбицкая 1996: 320).

Оптимальное соотношение между личностным началом и чертами, усвоенными как требование групповой, организационной, национальной и иной принадлежности, дает личности то сознание собственной идентичности, которое, не будучи следствием слепого конформизма, в то же время создает ощущение своего «я», гармонично сосуществующего с окружающей социальной средой. Многослойность личностной идентичности, базирующаяся на сложном сочетании психофизиологических, социальных, национально-культурных и языковых различий, возрастает по мере включения человека в более крупные культурно-языковые сообщества. Исследователи уподобляют современную концептуализацию идентичности русской матрешке, где одна идентичность входит в другую, составляя своего рода иерархическую структуру (Herrmann et al. 2004).

Типизированная лингвокультурная личность выступает как «носительница принятых норм и ценностей, доминирующих в определенном обществе», вписанная «в общую систему регуляции» и в результате предстающая «как фрагментарная и частичная личность, как носитель разных ролей, относящихся к разным сферам и типам культуры» (Ерасов 1997: 237-240).

В современном мире проблемы идентичности обретают новые формы и воплощения. Географическая мобильность, процессы глобализации, этническая и культурная полифония приводят к формированию так называемых множественных идентичностей, определяемых В.С. Курске как «отнесение себя < ..> к двум и более этническим культурам»: «наряду с традиционными диаспорами, такими как евреи, армяне, греки, немцы и т. д., возникают новые этнические сообщества с многоуровневым самосознанием, в котором накладываются и интегрируются различные элементы гражданской, региональной, конфессиональной и этнической идентичностей» (Курске 2011). Существовавшие прежде проблемы территориальности, сопряженные с географическими границами проживания этнических групп (demarcation of territories and identities), заменяются проблемами «детерриторизации» сообществ (de-territorialisation of communities) (Leung et al. 2009). 
В контексте культурного плюрализма (мультикультурализма, транснационализма) личностная идентичность предстает в новых ипостасях, где «трансформация» выступает как ключевой признак.

В статье Ф. Заппеттини "Transnationalism as an Index to Construct European Identities: An Analysis of 'Transeuropean' Discourses” («Роль транснационализма в конструировании европейских идентичностей: анализ „транс-европейских“ дискурсов») процессы формирования новых идентичностей трактуются как многогранные динамические конструкты. Транснационализм рассматривается на примере Европейского Союза, созданного сравнительно недавно и переживающего непростые времена - трансформацию европейской идентичности — "transformations of Europe(anness)". Автор пишет о зарождающихся постнациональных идентичностях, новых формах принадлежности, которые интересны для исследователей дискурса именно тем, что являются не раз и навсегда устоявшейся данностью, а результатом переговорного - далеко не всегда гладкого и бесконфликтного - процесса. Транснациональные дискурсы развиваются снизу вверх и конструируются на уровне межличностной, публичной и массовой коммуникации.

Цель автора - показать диалогическую природу этого процесса и роль языковых приемов и дискурсивных стратегий в формировании новых форм идентичности. В центре его внимания - роль индексальности в широком смысле (например, регионального акцента, идеологических и социальных коннотаций, разного рода импликатур, позиционирования себя во времени, пространстве, системе геополитических отношений) и дейксиса в более узком понимании (личных и указательных местоимений, наречий, ярлыков как показателей принадлежности к социальным группам и т. д.). Происходит отрыв английского языка как средства межкультурного общения от традиционно связываемых с ним географических территорий ('deterritorialisation'), эволюционируют бытующие в нем культурные и когнитивные коннотации. Европейская идентичность меняется под воздействием двуязычия.

С другой стороны, возникают «промежуточные» идентичности людей, которые не чувствуют себя в полной степени ассимилированными европейцами в силу недостаточного владения языком страны проживания, различия между публичным и семейным дискурсом, разделения морального долга перед обществом и аффективной, ценностной принадлежности к «близкому кругу». По мнению Ф. Заппеттини, национально-этническая принадлежность уходит, уступая место общеевропейской.

С работой Ф. Заппеттини в известной степени перекликается статья Ж.-М. Деваеле и Л. Хриниевич, в которой речь идет о межкультурной идентичности ромасловацких школьников в Великобритании. Авторы также полагают, что в современных условиях значимость этнического происхождения размывается, уступая место глобальной идентичности. Следует, однако, заметить, что идентичность многолика и бытует в форме глобального, национального, этнического, регионального и «местечкового» самопозиционирования. По-прежнему существует стремление сохранить собственную этническую идентичность, о чем свидетельствуют многочисленные политические процессы в современной Европе и в мире в целом. 
Ж.-М. Деваеле и Л. Хриниевич размышляют о роли этих процессов на примере достаточно малочисленной группы рома-словацких школьников, волею судьбы оказавшихся в Великобритании. Попадая в новое лингвокультурное пространство, экспатриант должен быть готов к тому, что его идентичность будет восприниматься иначе, чем в родной культуре. Для читателей данного журнала, чьи интересы в значительной степени сосредоточены на лингвистических проблемах, большой интерес может представлять конструирование идентичности в многоязычном обществе, где престиж и ценность разных языков оцениваются неодинаково и в разной степени ассоциируются с властью, статусом и другими показателями общественной жизни. В лингвистической литературе хорошо освещены проблемы языковой/культурной экспансии, языка как средства доминирования либо объекта дискриминации, формирования стереотипов из-за использования того или иного языка, восприятия личности на основе уровня ее языковой компетенции, поглощения одних языков другими и, как следствие, исчезновения языков. Потеря языка теснейшим образом ассоциируется с потерей идентичности. В условиях билингвизма или многоязычия различные языки могут выполнять разные функции и высвечивать разные стороны личностной и групповой идентичности.

Использование рома-словацких школьников в качестве объекта анализа позволяет на примерах проследить вышеуказанные процессы. Самоназвание этнической группы «рома» создает определенные трудности для интерпретации, так как оно включает в себя не только цыган, но и другие этногруппы (кале, синти и т.д.). С одной стороны, их проживание в Великобритании предполагает использование английского языка как основного. С другой стороны, утверждают авторы статьи, члены этнической группы могут восприниматься как «чужие», если они будут отдавать предпочтение английскому перед своим родным языком. Ж.-М. Деваеле (Dewaele 2010) полагает, что в процессе языковой адаптации, приспособления к новым языковым условиям может меняться и самовосприятие личности. Исследователи на основе анализа практического материала показывают, что переключение кодов (в данном случае речь идет о естественных языках) может происходить с целью: 1) достижения взаимопонимания с собеседником; 2) реализации дихотомии «свои - чужие»; 3) умения «существовать», «жить» в новом языковом пространстве.

Проблема дейксиса как показателя личностной идентичности в японском языке рассматривается в статье Етсуко Ойши “Discursive functions of Japanese personal pronouns" («Дискурсивные функции японских личных местоимений»). По мнению автора, идентификация функций местоимений первого и второго лица в иллокутивном акте позволяет последовательно охарактеризовать коммуникантов с точки зрения гендерной принадлежности, социальной ситуации, а также степени формальности во взаимоотношениях между ними. Для русского читателя чрезвычайно интересна дифференциация японских мужских (watakushi, watashi, boku и ore) и женских (watakushi, watashi и atashi) местоимений первого лица, определяющих самопозиционирование говорящего в зависимости от характера дискурса и социального контекста. Местоимения второго лица, в свою очередь, в дополнение 
к гендеру (мужские anata, kimi, anta и omae; женские anata и anta), обозначают их позиционирование во времени и пространстве и степень равенства / иерархичности между собеседниками.

В статье М. Оливейра и К. Лисбоа "Narratives about Displacement and Stigmatization of Identities” («Нарративы об утрате социального статуса и стигматизации идентичности») рассматривается проблема самовосприятия личности и ее восприятия со стороны окружающих через повествование. Результатом становятся альтернативные идентичности. Как известно, нарратор обладает большой властью, решая, что и как рассказывать, в каком порядке выстроить события и как объяснить мотивы своих действий. Именно это показано в статье бразильских ученых, которые исследуют механизм конструирования дискурсивной идентичности нарратора на основе повествования женщины из штата Рио-де-Жанейро, потерявшей дом в результате стихийного бедствия и оказавшейся бездомной со своими восьмерыми детьми. Доминантой в ее дискурсе оказываются темы женской доли и материнства. При этом она не хочет ассоциировать себя с другими бездомными и критически относится к их асоциальному поведению, демонстрируя при этом двойные стандарты при оценке собственных и чужих жизненных обстоятельств.

Статья Б. Лоестер “' A significant part of an insignificant identity': tradition, globalisation and the re-articulation of North-East Scots" («,,Значительная часть незначительной идентичности“: позиционирование северо-восточного шотландского языка между традицией и глобализацией») интересна для российского читателя тем, что в ней рассматривается не слишком часто обсуждаемая в отечественной лингвистике тема - статус шотландского языка «скотс» (диалект, региональный вариант или литературный язык?). Особое внимание уделяется северо-восточному шотландскому языку (North-East Scots) и конструированию идентичности его носителей, особенно в сельской местности и небольших городках, которая, по мнению автора, главным образом зиждется на сочетании их региональной и профессиональной принадлежности, а также ощущении своей исключительности по сравнению с носителями других диалектов и региональных вариантов. Проведенный автором опрос позволяет сделать выводы о том, что респонденты считают средствами сохранения статуса языка и своей идентичности использование шотландского языка в противовес английскому, наличие печатных материалов и изучение художественной литературы на этом языке.

\section{ТЕКСТ И ДИСКУРС}

Вторая часть журнала продолжает тему дискурса, поднятую в предыдущих выпусках. В контексте настоящего выпуска дискурс выступает как интегративный фактор, объединяющий различные по своей тематике исследования.

В статье Г.Г. Хазагерова «Коммуникативная культура в свете противопоставления полемического и проповеднического начал» дифференцируется влияние полемических и эпидейктических жанров на культивирование горизонтальных и вертикальных общественных связей, а также вклад этих жанров в культуру. Эпидейктические речи связываются с новыми разновидностями дискурсов в пропа- 
ганде, рекламе, гомилетике и дидактике; полемическое начало рассматривается в отношении как диалогических, так и монологических текстов. Автор размышляет о сложности устройства современного коммуникативного пространства и возможностях гармоничного сочетания в обществе полемических и неполемических жанров.

Статья И.А. Щировой «Текст как элемент интеграционного научного пространства» посвящена соотношению в тексте таких дихотомий, как наука и искусство, научная и художественная истина, научная и художественная картины мира, рациональное и чувственное познание, научная и эстетическая информация. Эссе, которое, с точки зрения автора, является произведением искусства и науки, трактуется как сочетание этих оппозитивных характеристик. Таким образом, в статье постулируется холистический подход к тексту, в пространстве которого реализуются тесные концептуальные связи между обозначенными выше понятиями.

В работе М. Э. Конурбаева "Redefining Neutrality in Language and Discourse" («О разграничении нейтральности в языке и речи») нейтральная лексика рассматривается как «база стилистической вариативности», на фоне которой интенсифицируется эстетическое восприятие стилистически маркированных единиц речи. Автор полагает, что в различных контекстах языковые единицы в разной степени используют свой семантический потенциал. На примере отрывков из разнотипных текстов автор показывает, каким образом создаются зоны стилистического воздействия, составляющие визуальную и звуковую образность текста.

A. Соуса, автор статьи " $A$ discourse-based view in interdisciplinary approaches to fictional text analysis” («Дискурсивно-ориентированные междисциплинарные подходы к анализу художественных текстов»), посвященной педагогической стилистике, прибегает к критическому дискурс-анализу, чтобы показать потенциал воздействия литературных произведений в дискурсивном и социальном контекстах. Чтение трактуется не как механическое упражнение, нацеленное на понимание прочитанного, а как интегративное умение и значимый вид диалогической деятельности в условиях педагогического процесса. При таком подходе дискурсанализ выступает как средство творческого интерактивного восприятия художественного текста, совместного творения смыслов писателем и читательской аудиторией.

В статье Е.Г. Которовой «,Обешание“ как модель речевого поведения: методика контрастивного анализа (на материале русского и немеикого языков)» предложен инновационный подход к сопоставительному анализу базовых единиц внутри- и межкультурной коммуникации. Принимая за основную единицу коммуникации «модель речевого поведения», автор полагает, что ее иллокутивное содержание и общая организация универсальны, а языковая реализация культурноспецифична и может существенно различаться в разных языковых сообществах. В работе детально описана структура модели и проиллюстрированы возможности ее применения на примере речевого акта «обещание» в русском и немецком языках. 
Выпуск завершает работа Н.В. Гладкой «Логоэпистемы в креолизованных текстах интернет-дискурса», написанная на материале мемов, демотиваторов, интернет-комиксов, эдвайсов и т. д. Логоэпистемы представляют собой трансформированные прецедентные высказывания в составе таких текстов, где вербальная и визуальная составляющая обыгрывают разные значения одной и той же лексической единицы. В статье предлагается классификация логоэпистемных единиц с учетом их национально-культурных особенностей и фоновых знаний адресатов.

Обсуждение социолингвистических проблем, а именно коммодификации русского языка, будет продолжено и в следующем выпуске журнала под редакцией Себастьяна Мута (Фрибурский университет, Швейцария) и с участием Анеты Павленко (Университет Осло).

(C) Olga A. Leontovich / O.А. Леонтович, 2017

\section{СПИСОК ЛИТЕРАТУРЫ / REFERENCES}

Богин Г. И. Современная лингводидактика: Учеб. пособие. Калинин: КГУ, 1980 [Bogin, G.I. (1980) Sovremennaja lingvodidaktika. (Modern Linguodidactics). Kalinin: KGU (In Russ).]

Вежбицкая А. Язык. Культура. Познание. М.: Рус. словари, 1996 [Wierzbicka, А. (1996) Jazyk. Kul'tura. Poznanie. (Language. Culture. Cognition.). Moscow: Rus. Slovari (In Russ).]

Ерасов Б.С. Социальная культурология. М.: Аспект Пресс, 1997 [Erasov, B.S. (1997) Social'naja kul'turologija. (Social Cultural Studies). Moscow: Aspekt Press (In Russ).]

Курске В.С. Множественная этническая идентичность: теоретические подходы и методология исследования. 20011 [Электронный ресурс]. URL: (дата обращения 09.03.2017) [Kurske,V.S. (2011) Mnozhestvennaja jetnicheskaja identichnost': teoreticheskie podhody i metodologija issledovanija. (Multiple Ethnic Identity: Theoretical Approaches and Research Methodology). Available at: http://www.dissercat.com/content/mnozhestvennaya-etnicheskayadentichnost-teoreticheskie-podkhody-i-metodologiya-issledovani (In Russ.)]

Blommaert, J. (2005) Discourse. A Critical Introduction. Cambridge: Cambridge University Press.

Dewaele, J.-M. (2010) The perception of French by native speakers and advanced L2, L3 and L4 learners. In V. Regan \& N. Chasaide (eds.), Language Practices and Identity Construction in French. Bern: Peter Lang, 133-156.

Fairclough, N. (2003) Analysing Discourse. New York: Routledge.

Fairclough, N. \& Wodak, R. (1997) In T.A. van Dijk (ed.), Discourse Studies. A Multidisciplinary Introduction, Vol. 2. Discourse as Social Interaction. London: Sage, 58-84.

Fowler R., Hodge B., Kress G., Trew T. (1979) Language and Control. London: Longman.

Herrmann, R.K., Risse-Kappen, T. \& Brewer, M.B. (2004) Transnational identities: becoming European in the EU. Oxford: Rowman \& Littlefield.

Leung, H., Hendley, M., Compton, R., \& Haley, B. (eds.) (2009) Imagining Globalisation: Languages, Identities and Boundaries. New York: Palgrave Macmillan.

\section{For citation:}

Leontovich, O.A. (2017). "A Mirror in which Everyone Displays their Image": Identity Construction in Discourse. Russian Journal of Linguistics, 21 (2), 247-259. 


\section{Для цитирования:}

Леонтович О.А. «Зеркало, в котором каждый показывает свой лик»: дискурсивное конструирование идентичностей // Вестник Российского университета дружбы народов. Серия: Лингвистика. 2017. Т. 21. № 2. С. 247-259.

\section{Bio Note:}

Olga A. Leontovich, Dr, Professor at Volgograd State Socio-Pedagogical University, Chair of the Department of Intercultural Communication, Head of the Center of Communication Studies, Director of the American Studies Center, Volgograd State Pedagogical University, member of editorial board of Russian Journal of Linguistics. Research Interests: General Linguistics and US-Russian Intercultural Communication. Contact information: e-mail: olgaleo@list.ru

\section{Сведения об авторах:}

Ольга Аркадьевна Леонтович, доктор филологических наук, профессор, заведующая кафедрой межкультурной коммуникации ВГПУ, заведующая Лабораторией коммуникативных исследований, директор Центра американистики, член редколлегии журнала Вестник Российского университета дружбы народов. Серия: Лингвистика. Сфера научных интересов: общая теория коммуникации, межкультурная коммуникация между русскими и американцами. Контактная информащия: e-mail: olgaleo@list.ru 